\title{
A PROCURA D'O CAMINHO DE GILGAMESH (RIO DE JANEIRO, 1937; LISBOA, 1967), OU SEMBLANÇA DE GREGORIO NEYNES
}

Bairon Oswaldo Vélez Escallón

UFSC

RESUMO: Este trabalho apresenta 0 livro 0 caminho de Gilgamesh: vestígios para a reconstituição de um bailado, publicado sob o pseudônimo Gregorio Neynes, em 1937, no Rio de Janeiro, e reeditado em 1967, em Lisboa. Livro raro, e não incluído em histórias da literatura ou do pensamento apesar da sua presença nas bibliotecas e arquivos pessoais de Mario de Andrade e Guimarães Rosa, trata-se de uma constelaç̧ão de aforismos que se apresentam como a transcrição dos passos do herói sumério Gilgamesh, gravados em fragmentos de argila. Este artigo descreve de maneira geral essa constelação, a circunstância do seu achado, e tenta a sua inserção numa série literária que, talvez, permita a legibilidade que a sua própria obscuridade parece impedir.

PALAVRAS-CHAVE: Neynes. Guimarães Rosa. Arquivo. Antropofagia. Estilo vestigial. Literatura brasileira.

\section{LOOKING FOR O CAMINHO DE GILGAMESH (RIO DE JANEIRO, 1937, LISBON, 1967) OR GREGORIO NEYNES'S SEMBLANCE}

\begin{abstract}
This paper discusses the book 0 Caminho de Gilgamesh: vestígios para a reconstituição de um bailado, published in 1937 by the pseudonym Gregorio Neynes, in Rio de Janeiro, and republished in 1967, in Lisbon. Rare book, not included in histories of literature or Brazilian thought despite their presence in libraries and personal archives of Mario de Andrade and Guimarães Rosa, 0 Caminho de Gilgamesh is a constellation of aphorisms that are presented as the transcriptions of the steps of the Sumerian hero Gilgamesh. This article describes that constellation, the circumstance of his finding, and tries its inclusion in a literary series that allows legibility for Neynes's book.
\end{abstract}

KEYWORDS: Neynes. Guimarães Rosa. Archive. Anthropophagy. Vestigial style. Brazilian literature. 


\title{
A PROCURA D'O CAMINHO DE GILGAMESH (RIO DE JANEIRO, 1937; LISBOA, 1967), OU SEMBLANÇA DE GREGORIO NEYNES ${ }^{1}$
}

\author{
"Se eu cair, deixarei então um nome que ficará para a posteridade..." \\ A epopeia de Gilgamesh, 2.500-2.000 a.C. \\ “En el instante en que yo dejo de creer en él, 'Averroes' desaparece." \\ Borges, "La busca de Averroes", 1949.
}

Em castelhano existe a palavra semblanza, que designa um perfil biográfico, uma nota que recolhe a vida de alguém que mereceria ser lembrado. Dado que agora falarei de livro de autor inventado, ou anômico, ou simplesmente desconhecido, e achado no arquivo, e dado que falo como estrangeiro, peço licença para neologar, subtitulando este trabalho da maneira que está acima. Não posso contar o nome verdadeiro do autor de que trata esta "semblança", ou melhor, não sei se o nome de que dispomos é nome "verdadeiro" ou apenas um pseudônimo. Pelo mesmo motivo, este texto não é exatamente um perfil biográfico de Neynes, mas um comentário sobre a sua obra visível, de breve e fácil enumeração. Valha o desvio da semblanza, em nome da lembrança, precisamente, de um nome, ou dois.

Todavia, antes de falar sobre livro e autor, preciso dizer o contexto em que soube da sua existência. Foi no arquivo de Guimarães Rosa, onde estava à procura de informações sobre as passagens desse escritor pela minha cidade,

\footnotetext{
${ }^{1}$ Este trabalho é resultado da minha participação no Seminário de pesquisa entre os alunos do PROCAD (Pós-Graduação Ciência da Literatura da UFRJ e Pós-Graduação em Literatura da UFSC), ocorrido no dia 16 de outubro de 2015. Faz parte, também, das atividades que atualmente desenvolvo em instância pós-doutoral, junto ao Programa de Pós-Graduação em Literatura da Universidade Federal de Santa Catarina, com supervisão da Profa. Dra. Susana Scramim. Agradeço a Ana Barata, Bibliotecária de referência da Biblioteca de Arte/ Fundação Calouste Gulbenkian (Lisboa), pelo envio do "POEMA" de Gregório Neynes citado neste trabalho; da mesma maneira, agradeço aos funcionários do Centro de Documentação Cultural "Alexandre Eulalio" (CEDAE) da UNICAMP por me auxiliar na consulta do Fundo Flávio de Carvalho. Especialmente, agradeço à Dra. Luz Adriana Sánchez Segura, cujo trabalho de pesquisa foi fundamental na escrita deste artigo, ao Prof. Dr. Gustavo de Castro pelo fornecimento da tese de Elizabeth Hazin, ao Prof. Dr. Eduardo Sterzi por seus comentários, e à Dra. Larissa Costa da Mata pela sua leitura atenta e pelo contato e informações que para mim obteve do Prof. Dr. Rui Moreira Leite a respeito de Flávio de Carvalho. Finalmente, agradeço a leitura atenta e as sugestões da Dra. Maryllú Caixeta e as averiguações do Prof. Dr. Raúl Antelo.
} 
Bogotá, e sobre um conto em que, de maneira elíptica e barroca, ele relata essas passagens, assim como os desastres que por lá aconteciam nesses anos, a década da Violência, 1940. Esse conto de Guimarães Rosa se intitula "Páramo". ${ }^{2}$ É um conto, digamos, reversível, acaba da mesma maneira que começa, um conto sobre a vida póstuma, sobre a vida que emana de uma catástrofe cósmica impossível de superar pelas vias do sujeito ou do fechamento identitário.

Para além dessas considerações sobre o conto, que já trabalhei extensamente em outros lugares, interessa dizer que, em anotações preparatórias, achei em 2013, no Instituto de Estudos Brasileiros da Universidade de São Paulo (IEB/USP), uma lista com possíveis epígrafes das partes ou fragmentos que compõem "Páramo". A seguir, reproduzo uma transcrição dessa lista: ${ }^{3}$

\footnotetext{
2 ROSA, João Guimarães. Estas estórias. José Olympio: Rio de Janeiro, 1968.

${ }^{3}$ Lamentavelmente, não disponho de uma reprodução digital do documento arquivado sob os cuidados do Instituto de Estudos Brasileiros da Universidade de São Paulo. Isso, além de não permitir uma visão direta do documento, impede o recurso a dispositivos como a transcrição diplomática. A estrutura arquivante, neste caso, é a própria mão do pesquisador, e isso faz com que detalhes como os tipos, as cores das tintas usadas; as qualidades, matérias, e formatos dos suportes; os carimbos, timbrados, rasuras, acidentes, etc., não sejam aqui reproduzíveis. Apesar do imenso cuidado empregado na transcrição do documento, as próprias disposições das grafias sobre o papel poderão estar alteradas. Esta página se encontra entre os materiais da pasta "Religião (Citações e cabala)", do acervo "João Guimarães Rosa", tombada pelo IEB/USP com o número catalográfico JGR-EO-08,02.
} 
PÁRAMO

$-\boldsymbol{\Omega}-$

"Com efeito, não me surpreenderia (que) fosse verdadeiro o [dito por] Eurípides: Quem sabe se a vida não é uma morte e a morte uma vida?"

PLATÃO, « Górgias »

$-\Psi-$

$$
\left\{\begin{array}{r}
\text { Lao-Tse } \\
\text { O culi cão } \\
\text { Trismegisto }
\end{array}\right\}
$$

$-\mathrm{X}$

$\infty$

«Não atentando nós nas coisas que se vêem, mas nas que se não vêem: porque as coisas que se vêem são temporárias, e as que se não veem são eternas»

São Paulo, "Corintios, II, 4:18.

$-\Gamma-$

«Talvez estejamos mortos realmente, nós, como escutei a um sábio, o qual pretendia que a nossa vida atual é uma morte, nosso corpo um túmulo...

$$
\text { PLATÃO, « Górgias » }
$$

$-B$ -

"Para cima não se vae -volta-se"

GREGÓRIO NEYNES, "O caminho de Gilgamesh"

$-\mathbf{A}-$

"Pensamos sempre que estamos fazendo (algo), quando, na realidade, não fazemos nada -tudo acontece."

OUSPENSKY, "A quarta via"

Entre outros motivos, me interessou essa citação de Neynes porque, no contexto das anotações de Rosa, parece fazer referência à altitude de Bogotá, uma temática autobiográfica muito explorada em "Páramo". É claro que também há na citação uma referência ao eterno retorno nietzschiano, eterno retorno que retorna na citação do Górgias de Platão que acabou sendo usada como epígrafe de "Páramo" ("Quem sabe se a vida não é uma morte e a morte uma vida?"); ou na conhecidíssima sentença do Corpus Hermeticum (100-300 d.C.) de Trismegisto ("O que está embaixo é como o que está em cima, e o que está em cima é como o que está embaixo"); ou no Tao-Te-King (300 a.C.), de Lao-Tse, talhado em réguas de bambu de ordenações e combinações variáveis; ou no CÚLI CÃO, autor inventado que foi parar numa das epígrafes 
das estórias do Livre Tutaméia, livro reversível e rizomático, como o próprio nome "cúli cão", que parece designar "cola↔cabeça": Cúli (coolie, o trabalhador braçal maltratado no Tufão de Joseph Conrad) e Cão (Khan, o chefe, o comandante, o rei). Além dessa lembrança nietzschiana, a citação d'O caminho de Gilgamesh parece remeter também à própria circularidade da narrativa assinada por Rosa:

\section{Para cima não se vae -volta-se. ${ }^{4}$}

Esse é o aforismo 491 do livro $O$ caminho de Gilgamesh: vestígios para a reconstituição de um bailado (1937), de Gregorio Neynes. Note-se a semeIhança desse subtítulo com os títulos O bailado do deus morto (1933) e Notas para a reconstrução de um mundo perdido (1957-1958)5 , do "arqueólogo malcomportado" Flávio de Carvalho. Por vários motivos, pode-se dizer que Neynes é um antropófago desconhecido e que $O$ caminho de Gilgamesh parece obra produzida segundo uma ciência do vestígio errático. ${ }^{6}$ Sem editora

\footnotetext{
${ }^{4}$ NEYNES, Gregorio. O caminho de Gilgamesh: vestígios para a reconstituição de um bailado. Rio de Janeiro: Irmãos Pongetti, 1937, s/p.

${ }^{5} \mathrm{O}$ bailado do deus morto foi um polêmico espetáculo de teatro-dança de autoria de Flávio de Carvalho, para o qual criou, aliás, cenografia e figurino. Os atores-dançarinos, em sua maioria negros, usavam na representação máscaras de alumínio. O Teatro da Experiência, sob a alegação de ser atentatório aos bons costumes, foi fechado pela polícia do Rio de Janeiro, após a terceira apresentação dessa peça, em 1933. O texto de O bailado do deus morto, junto com o ensaio $A$ origem animal de deus, só seria publicado em livro em 1973: CARVALHO, Flávio de. A origem animal de deus / O bailado do deus morto. São Paulo: DIFEL, 1973. Notas para a reconstrução de um mundo perdido, por sua vez, é um conjunto de 65 textos de Flávio de Carvalho publicados no Diário de S. Paulo, entre janeiro de 1957 e setembro de 1958. Os primeiros vinte e quatro textos da série aparecem sob o título Os gatos de Roma. A partir da nota 25 , a série passa a ser intitulada Notas para a reconstrução de um mundo perdido. Para a preparação deste texto, consultei a transcrição dessa série na tese: Cf. DA MATA, Larissa Costa. Genealogia e primitivismo no mundo perdido brasileiro: o mundo perdido de Flávio de Carvalho. Tese (Doutorado), Programa de Pós-Graduação em Literatura, Universidade Federal de Santa Catarina Florianópolis, 2013, p. 415-634.

${ }^{6}$ Neste ponto, e para desde já introduzir algo do "estilo de pensamento" de Neynes, estou fazendo referência a dois textos de Oswald de Andrade - "Mensagem ao antropófago desconhecido" (1946) e A crise da filosofia messiânica (1950) - em que se postula a necessidade de uma "ciência do vestígio errático". Gonzalo Aguilar abordou essa nova ciência, a errática, em estudo de 2010: Cf. AGUILAR, Gonzalo. Por una ciencia del vestigio errático (ensayos sobre la antropofagia de Oswald de Andrade). Buenos Aires: Grumo, 2010. Como já deve ser evidente, adoto neste texto uma metodologia afim com o que parece sugerido por esses textos: uma reflexão que poderia se localizar como participando de um "paradigma indiciário" [GINZBURG, Carlo. Mitos, emblemas, sinais: morfologia e história. Trad. Federico Carotti. São Paulo: Companhia das Letras, 1989, p.143-180], no caso de não me produzir alguma desconfiança essa palavra - paradigma - pelo que pode ressoar nela de modelo representacional de um dado saber. Talvez seja mais adequado, devido ao distanciamento a
} 
ou paginação, editado após pagamento do autor aos impressores Irmãos Pongetti (Rio de Janeiro, 1937), sem figurar o nome autoral (possivelmente um pseudônimo) nas histórias da literatura, ou só com alguns raros exemplares em alguma exígua biblioteca, evidentemente, Neynes é um desconhecido e $O$ caminho de Gilgamesh um livro bastante obscuro. Mas dois exemplares dessa edição de 1937, com dedicatórias autógrafas a Guimarães Rosa e a Mário de Andrade, podem ser vistos nas respectivas bibliotecas desses escritores, hoje sob os cuidados do IEB/USP:

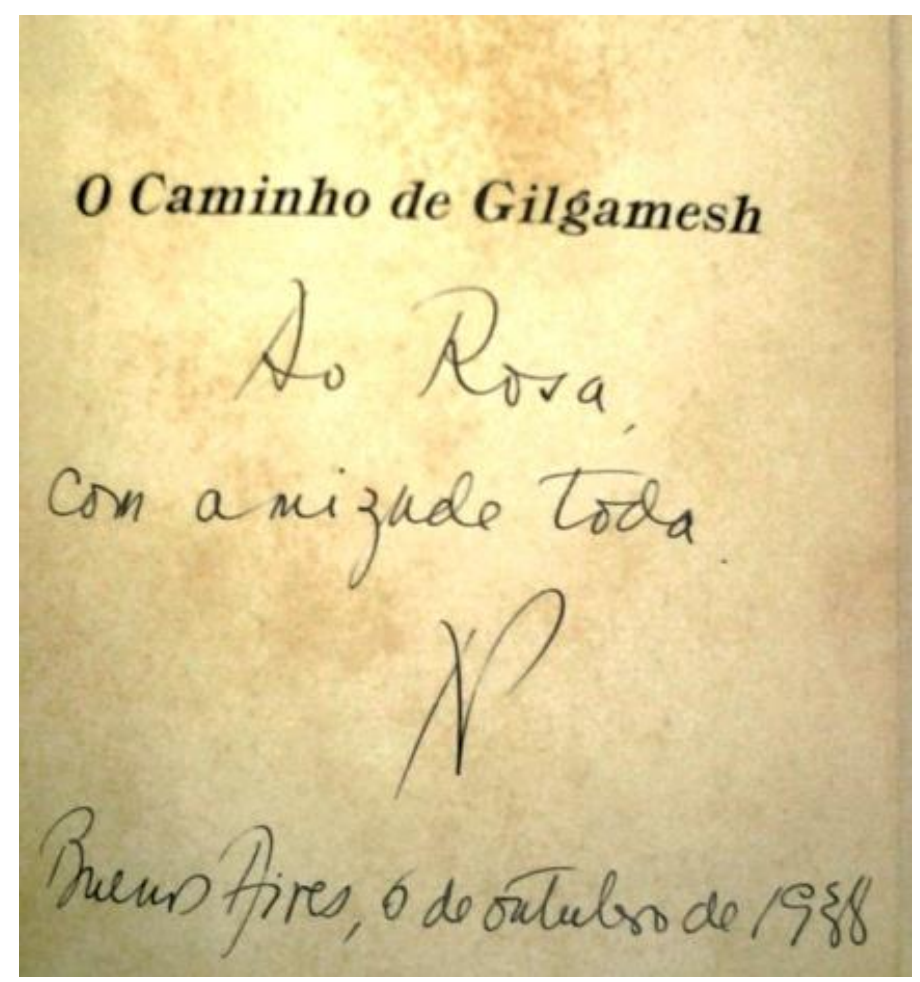

Figura 1 - Dedicatória de Gregorio Neynes n'O caminho de Gilgamesh. Exemplar pertencente a Guimarães Rosa.

respeito desse modelo, adotar um estilo de pensamento vestigial ou indiciário que, longe de se ocupar com conteúdos ou formas, atende a indícios, pistas, pegadas, fragmentos, sinais, vestígios, detalhes... Dado que em outros trabalhos abordei e explicitei essas opções metodológicas, que ocupariam demasiado espaço neste artigo, além de extrapolar seu propósito, remeto a ESCALLÓN, Bairon Oswaldo Vélez. O Páramo é do tamanho do mundo: Guimarães Rosa, Bogotá, lauaretê. Tese (Doutorado), Programa de Pós-Graduação em Literatura, Universidade Federal de Santa Catarina, 2014, p. 19-35. 


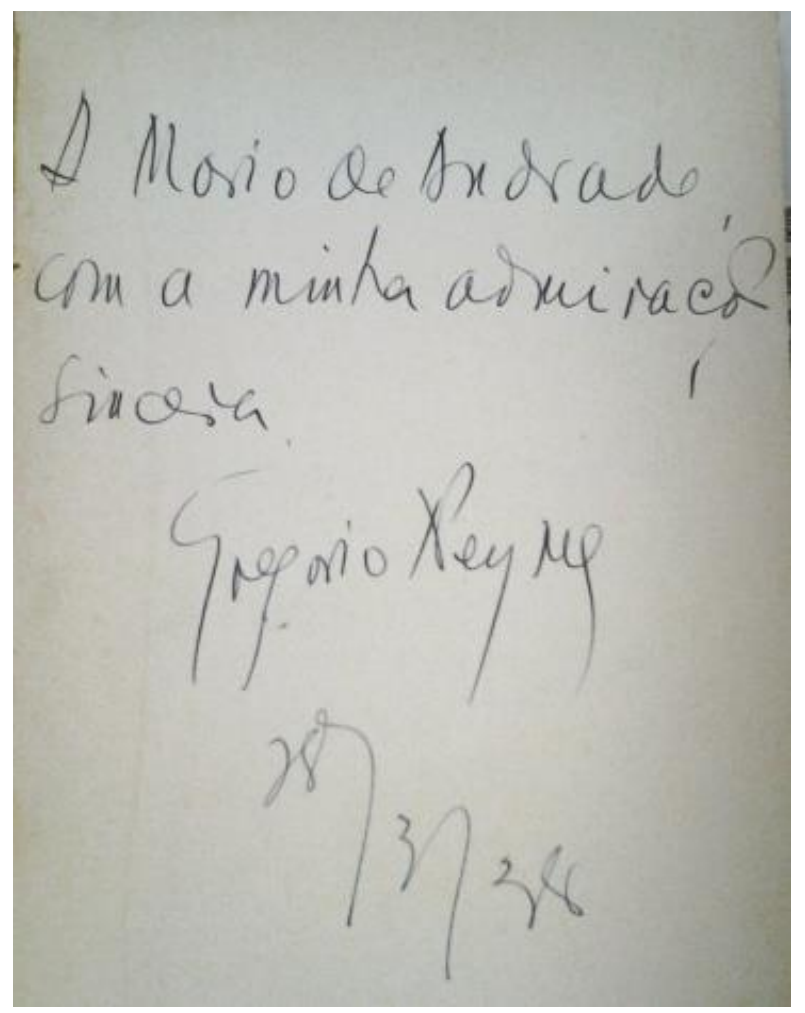

Figura 2 - Dedicatória de Gregorio Neynes n'O caminho de Gilgamesh. Exemplar pertencente a Mario de Andrade.

Note-se a confiança na dedicatória a Rosa: "Ao Rosa com amizade toda"7; a cidade e a data: Buenos Aires, 6 de outubro de 1938.

É fato conhecido que Guimarães Rosa, e principalmente a sua segunda mulher, Aracy Moebius de Carvalho, tiveram grande participação na emissão de vistos para judeus e pessoas por outros motivos ameaçadas pelo nazismo, entre os anos 1938 e 1942, da Embaixada brasileira em Hamburgo. Nessa ci-

\footnotetext{
7 Apesar de presente no arquivo rosiano, o nome Neynes foi até agora desconsiderado pela crítica especializada. Acredito que o desconhecimento do autor acaba desestimulando a sua citação em trabalhos acadêmicos - que, sabemos, geralmente optam pelo conhecido e comprovável. Suzi Frankl Sperber, por exemplo, em Caos e cosmos (1976), livro dedicado às leituras esotéricas de Guimarães Rosa, sintomaticamente opta por não abordá-lo, e Elizabeth Hazin, na sua tese No nada, o infinito (1991), dedicada aos materiais preparatórios de Grande Sertão: veredas, chega a utilizar O caminho de Gilgamesh em duas epígrafes sem, no entanto, mencionar que esse livro se encontra entre os volumes da biblioteca de Guimarães Rosa, hoje sob os cuidados do IEB/USP. Devo o acesso a essa tese ao Prof. Dr. Gustavo de Castro (UnB), que atualmente prepara uma biografia do autor de Tutaméia. Cf. SPERBER, Suzi Frankl. Caos e cosmos; leituras de Guimarães Rosa. São Paulo: Duas cidades, 1976; HAZIN, Elizabeth. No nada, o infinito (da gênese do Grande Sertão: veredas). Tese (Doutorado), 1991. Universidade de São Paulo, Departamento de Letras Clássicas e Vernáculas, Faculdade de Filosofia, Letras e Ciências Humanas.
} 
dade Rosa desempenhou labores como Cônsul adjunto a partir de maio de $1938^{8}$, mas Aracy de tempos atrás já vinha intervindo, corajosamente, na emissão de vistos para pessoas ameaçadas pela febre antissemita. Bem, acontece que nos jornais $A$ batalha e Diário carioca, do Rio de Janeiro, em 10 de setembro de 1939 , se faz a relação de passageiros brasileiros, a bordo do navio Siqueira Campos, embarcados em Hamburgo, Rotterdam, Antuérpia, Havre, Vigo, Leixões e Lisboa. Segundo esses veículos de imprensa, o Siqueira Campos deixou Lisboa no dia 6 de setembro de 1939 trazendo 282 passageiros, entre os quais consta Nelson Geraldo Esteves. ${ }^{9}$ Esse nome, Nelson Geraldo Esteves, também consta da lista de passageiros do navio Antonio Delfino, que aportou em Buenos Aires no dia 11 de abril de $1938^{10}$ (a dedicatória a Rosa é de 6 de outubro do mesmo ano, e se assina na capital argentina) trazendo imigrantes judeus em fuga da Europa. Nesse último registro, se afirma que Esteves nasceu no Rio de Janeiro e tem 25 anos de idade. Como veremos mais adiante, essas informações coincidem surpreendentemente com outras que achei na minha procura pelo autor e o livro de que trata este trabalho, mas, por enquanto, podemos inferir que essa pessoa de 25 anos pode ser um dos judeus auxiliados por Aracy para sair da Alemanha em tempos sombrios, ou uma pessoa ameaçada por motivos ideológicos, ou políticos, ou um jovem diplomata retornando ao seu país.

Por que menciono esses fatos, esse nome errante, Nelson Geraldo Esteves?

Após intensa procura, foi possível achar um exemplar d'O caminho de Gilgamesh, edição de 1937, num sebo da cidade de São Paulo e, através da internet, encontrei uma reedição portuguesa de 1967 (Lisboa: Estúdios Cor), cujo texto introdutório vem com assinatura de "GREGÓRIO NEYNES Diretor da Secção de Pesquisas, Departamento de Arqueologia, Divisão de Restauração de Relíquias, Ministério de Conservação e Promoção das Artes". ${ }^{11}$ Nessa segunda edição, a orelha inicial do livro tem notas de apresentação de Tasso da Silveira e de Agrippino Grieco ${ }^{12}$ (um dos assinantes da carta de protesto

${ }^{8} \mathrm{Cf}$. BARBOSA, Alaor. Sinfonia Minas Gerais: a vida e a literatura de João Guimarães Rosa. Brasília: LGE, 2007, p. 178.

9 Versões digitais desses jornais podem ser visualizadas na Hemeroteca Digital Brasileira.

${ }^{10}$ Como consta nos dados do Centro de Estudios Migratorios Latinoamericanos (CEMLA).

11 GERALDO, Nelson. O caminho de Gilgamesh: vestígios para a reconstituição de um bailado. Lisboa: Estúdios Cor, 1967, s/p.

12 Transcrevo, aqui, essas notas na orelha da reedição de 1967. A primeira, de Agrippino Grieco, diz: "Ou muito nos enganamos ou está aí alguém que amanhã será um dos nossos grandes aforistas filosóficos... tem o talento das definições concisas, cortantes, que obsedam a memória, exprimem muita emoção ainda confusa em nós, sublinham inúmeros acon- 
pelo fechamento do Teatro da Experiência pela polícia após a representação do $O$ bailado do deus morto ${ }^{13}$, no Rio de Janeiro, 1933), mas o nome impresso na capa não é mais Gregorio Neynes, senão Nelson Geraldo - o judeu errante que consta nas relações de passageiros dos navios Siqueira Campos e Antonio Delfino. Há outras modificações no corpo do livro. O texto introdutório, por exemplo, não se intitula mais "Introducção"14, nem está mais situado no Rio de Janeiro de "1933 a 1937"; na reedição, a introdução se intitula "O DRAMA AFORÍSTICO// ONDE SE DEMOSTRA QUE A MANEIRA MAIS FIRME DE PISAR NO CHÃO COM UM PÉ É LEVANTAR O OUTRO E RECÌPROCAMENTE", e se assina em nova cidade e nova data: "Londres, 1967". 15 Também a ortografia do primeiro nome de Neynes se modifica, passa de "Gregorio" a "Gregório", assinante do texto introdutório mencionado, assim como se atualiza e modifica a ortografia geral do livro. Uma última modificação importante: os aforismos se renumeram e diminuem, passam de 496 a 325 nessa reedição portuguesa.

Dentre todas essas modificações, destaco a troca de nomes de autor e das iniciais desses nomes: Gregorio Neynes/Nelson Geraldo, GN/NG. Essa inversão me parece simétrica àquela do aforismo 491, acima citado, e à própria reversibilidade do livro, que descreverei mais adiante, mas o que mais chama a minha atenção é que parece um jogo com o nome do autor, um indistinto, visto como está que, apesar da assinatura de Nelson Geraldo na capa, o nome "Gregório Neynes" é mantido como assinatura da introdução da edição de 1967. Com essa inversão, a identidade do escritor se mantém enigmática, mesmo no único artigo achado a respeito desse livro, uma resenha assinada por Tasso da Silveira e publicada no Diário de Notícias em 12 de setembro de

tecimentos da nossa vida mental e moral... o seu trabalho é daqueles que o Brasil não produz senão com largos interregnos". A segunda é um trecho extraído da resenha escrita por Tasso da Silveira para o Diário de Notícias (publicada em 12 de setembro de 1943): "O Caminho de Gilgamesh... é livro do qual, em outra terra, se teriam dito coisas agudas e penetrantes. Exatamente porque, sob seus múltiplos e provocadores aspectos, representa estímulo eficacíssimo à doce volúpia da especulação metafísica e estética... Mostra [o autor] à exageração que ele é do número dos que, como Mallarmé, como Valéry, como Stefan George, se decidiram pelas conquistas definitivas, que só os melhores espíritos apreendem, contra as conquistas perecíveis, que a sagração das maiorias tão facilmente coroa".

13 Outros assinantes dessa carta de protesto: Paulo Prado, Mário Pedrosa, Oswald de Andrade, Jaime Adour da Camara, Osório César, Caio Prado Júnior, Menotti del Pichia, Afonso Frederico Schmidt, Rubem Braga. Cf. CARVALHO, Flávio de. A origem animal de deus / O bailado do deus morto. São Paulo: DIFEL, 1973, p. 108.

${ }_{14}$ Manterei a ortografia dos originais, em todas as transcrições.

15 GERALDO, Nelson. O caminho de Gilgamesh: vestígios para a reconstituição de um bailado, op. cit. 
1943, texto que retomarei brevemente, assim como, mais adiante, retomarei um registro dos direitos autorais d'O caminho de Gilgamesh, publicado no Diário Oficial em 2 de junho de 1938.

Antes de me referir a esses documentos, entretanto, me parece adequado vincular a proveniência de Nelson Geraldo Esteves, assim como o deliberado jogo de inversão de nome e pseudônimo nas duas edições d'O caminho de Gilgamesh, com uma ideia elaborada pelo pensamento europeu não-sionista da primeira metade do século $X X$, e que tem expressão sintética em um aforismo das Palavras em verso (1916-1930), de Karl Kraus: "A Origem é o Alvo". ${ }^{16}$ Nas suas reflexões sobre "A tarefa do tradutor", publicadas em 1923 na edição alemã dos Tableaux Parisiens de Charles Baudelaire, Walter Benjamin retomava algo dessa ideia, apostando por uma tarefa tradutória que, longe de restituir o significado de um original, optava pela amorosa sobrevivência de um gesto, ou de um conjunto de gestos de escritura, na passagem de uma língua à outra. Isto é, alvejando a ideia do significado como origem, Benjamin apostava na repetição diferencial e na potência, na tradutibilidade e não na significação "original", na enunciação situada e não exclusivamente no enunciado. Em 1928, o Benjamin d'A origem do drama barroco alemão, retomava esse pensamento e postulava uma das suas mais célebres contribuições à modernidade: a saber, o Ursprung ou a origem, entendida como algo não simplesmente dado, ou seja, não como uma gênese (Entstehung) senão como algo originário, como aquilo que, ainda que histórico, não estabilizaria uma identidade ou presença, mas desataria um movimento inesgotável de gestação. A origem, assim entendida, estaria lançada a acontecer cada vez que reclamada, ela estaria no acontecimento de toda remontagem da história. ${ }^{17}$ Esse entendimento da origem, não como um retorno a uma protoforma, mas como Ursprung, o que pode valer como ida-e-volta, reversibilidade de tudo

${ }^{16}$ KRAUS, Karl apud BENJAMIN, Walter. Magia e técnica, arte e política: ensaios sobre literatura e história da cultura. Trad. Sergio Paulo Rouanet. São Paulo: Editora Brasiliense, 1993, p. 229.

17 "A origem, apesar de ser uma categoria totalmente histórica, não tem nada a ver com a gênese. $O$ termo origem não designa o vir-a-ser daquilo que se origina, e sim algo que emerge do vir-a-ser e da extinção. A origem se localiza no fluxo do vir-a-ser como um torvelinho, e arrasta em sua corrente o material produzido pela gênese. $O$ originário não se encontra no mundo dos fatos brutos e manifestos, e seu ritmo só se revela a uma visão dupla, que o reconhece, por um lado, como restauração e reprodução, e por outro lado, e por isso mesmo, como incompleto e inacabado. [...] A origem, portanto, não se destaca dos fatos, mas se relaciona com sua pré e pós-história". BENJAMIN, Walter. Origem do drama barroco alemão. Trad. Sergio Paulo Rouanet. São Paulo: Editora Brasiliense, 1984, p. 68. 
quanto é novo, entretanto, só teria a sua formulação mais clara, na tese 14 de "Sobre o conceito de história" (1940), tese que, não por acaso tem por epígrafe o aforismo de Karl Kraus acima citado:

\begin{abstract}
A história é objeto de uma construção cujo lugar não é o tempo homogêneo e vazio, mas um tempo saturado de "agoras". Assim, a Roma antiga era para Robespierre um passado carregado de "agoras", que ele fez explodir do continuum da história. A Revolução Francesa se via como uma Roma ressurreta. Ela citava a Roma antiga como a moda cita um vestuário antigo. A moda tem um faro para o atual, onde quer que ele esteja na folhagem do antigamente. Ela é um salto de tigre em direção ao passado. Somente, ele se dá numa arena comandada pela classe dominante. $\mathrm{O}$ mesmo salto, sob o livre céu da história, é o salto dialético da Revolução, como o concebeu Marx.18
\end{abstract}

Como sabemos, Benjamin cumpriria seu destino de heimatlos pouco depois da elaboração dessas teses na sua passagem entre a França e a Espanha, o mesmo destino representado por Lasar Segal em III Classe (1928) ou em Navio de emigrantes (1939/1941) e relatado por Oswald de Andrade em "Diálogo das vozes segalianas" (1944). ${ }^{19}$ Isso, a origem como alvo, parece um dos fundamentos do livro errante que este artigo pretende apresentar, $O$ caminho de Gilgamesh.

Esse "drama aphoristico", segundo a grafia de 1937, tem a pretensão de ser um Livro, um livro do tamanho do mundo, como se pode coligir da introdução: "O sentido do caminho que Gilgamesh perfaz [...] é uma compreensão do Universo." 20 Tasso da Silveira, de fato, na resenha de 1943, antes mencionada, empenha-se numa filiação nietzschiana - "Gilgamesh conheceu profundamente Zaratustra" - e mallarmáica desse livro, dizendo inclusive que se trata de viagem "de estrela a estrela, através dos espaços infinitos". ${ }^{21}$ É claro, isso está no livro, já na epígrafe da introdução:

18 Idem, Magia e técnica, arte e política: ensaios sobre literatura e história da cultura. Trad. Sergio Paulo Rouanet. São Paulo: Editora Brasiliense, 1993, p. 229-230.

${ }^{19} \mathrm{Cf}$. AGUILAR, Gonzalo. Por una ciencia del vestigio errático (ensayos sobre la antropofagia de Oswald de Andrade), op. cit.

20 NEYNES, Gregorio. O caminho de Gilgamesh: vestígios para a reconstituição de um bailado, op. cit., s/p.

21 SILVEIRA, Tasso da. O caminho de Gilgamesh. Diario de noticias, Rio de Janeiro, 12 set. 1943, p. 17. 


\title{
O DRAMA AFORISTICO
}

\author{
ONDE SE DEMOSTRA \\ QUE A MANEIRA MAIS FIRME DE \\ PISAR NO CHÃO COM UM PÉ \\ É LEVANTAR O OUTRO E \\ RECIPROCAMENTE
}

«... but stars.

\begin{abstract}
$A$ quatro anos do dia em que estamos escrevendo, alguém nos entregava o material mais curioso que já foi dado a um araueóloon nesauisar. ae nonada. d. .....
\end{abstract}

Figura 3 - Título, epígrafe e primeiras linhas da introdução a O caminho de Gilgamesh ${ }^{22}$

"But stars..." As palavras tornam-se estrelas em um céu de papel. Hermético, O caminho de Gilgamesh é apresentado, tanto na introdução de 1937 quanto na de 1967, como a reconstrução aforística dos vestígios - "hieroglipho[s]" - deixados em argila pelo bailado do herói sumério, uma transliteração de pegadas, ou "ideogramma de um estado de espírito feito gesto numa attitude mímica, num momento rythmico", segundo uma inovadora ciência/arte, uma gaia ciência, uma ciência do vestígio errático pós-Botta, pósChampollion, denominada "archeologia choregraphica"23 (cuidado: não é uma "choregrafia archeológica", adverte Neynes ${ }^{24}$ ). De maneira surpreendente, na mesma "introdução" recomenda-se atentar para as superposições de pegadas sobre pegadas, "verdadeiros palimpsestos", e para tudo que ficou sem gravar nas tabuletas de argila do Rey Asurbanípal, os intervalos ou "missing links" entre esses vestígios: "o leitor terá de deduzir movimentos que não deixaram

22 GERALDO, Nelson. O caminho de Gilgamesh: vestígios para a reconstituição de um bailado, op. cit., s/p.

23 Destaco mais uma coincidência com Flávio de Carvalho, que em "Um plano de 6 anos" (1939), fala em três períodos de reorganização do Salão de Maio: um período arqueológico, um período dialético e um período visionário. Cf. CARVALHO, Flávio. Um plano de 6 anos. Revista Anual do Salão de Maio, n. 1, São Paulo, maio 1939, p. 10.

${ }^{24}$ NEYNES, Gregorio. O caminho de Gilgamesh: vestígios para a reconstituição de um bailado, op. cit., s/p. 
trazo [...] completar a curva da qual damos os pontos de contato com este plano axial dos acontecimentos humanos -o chão." 25 Com outras palavras, Neynes, à maneira do Walter Benjamin de "Sobre a faculdade mimética" (1933), solicita "ler o que nunca foi escrito". ${ }^{26}$ Dessa atividade criadora, diferenciada das personificações próprias do "romance psychologico" e da "novel of ideas", Neynes declara esperar uma espécie de ressurreição de Gilgamesh, um deus que morre, a compreensão de que "Tudo é meio" (Tutaméia), de que basta abrir os olhos para compreender o mundo, e de que "só a experiência comunica os seres" numa "sympathia trágica" que está para além da intelecção. ${ }^{27}$

Essa simpatia trágica, esse deus que morre, essa ciência vestigial que quer reconstituir os passos da sua dança na terra, remetem a uma vasta genealogia que podemos, breve e precariamente, enumerar. Em primeiro lugar, penso em J. J. Bachofen que, a partir da consideração de uma promiscuidade originária entre vida e morte, e da sua perscrutação em monumentos funerários, chegava a elaborar, em 1861, a teoria de um matriarcado sobrevivente na cultura ocidental. Para Bachofen, o próprio conceito de autoridade, fundamentado na ordem patriarcal sobre o monopólio da violência e, portanto, sobre o crime e a expropriação, estaria no matriarcado completamente subvertido. Talvez por isso, Dioniso, o deus rebelde, impuro, um deus que morre, era para Bachofen um princípio feminino, um eco da voz silente das sereias esquecidas. ${ }^{28}$ Isso evidentemente tem desdobramentos, entre outros, na Origem da tragédia (1872) nietzschiana, nos deslocamentos sobreviventes do etnocentrismo europeu em Warburg e Carl Einstein, no Ursprung benjaminiano, ou no resgate

\footnotetext{
$25 \mathrm{Ibidem}, \mathrm{s} / \mathrm{p}$.

26 “'Leer lo que nunca ha sido escrito'. Tal lectura es la más antigua: anterior a toda lengua la lectura de las vísceras, de las estrellas o de las danzas. Más tarde se constituyeron anillos intermedios de una nueva lectura, runas y jeroglíficos. Es lógico suponer que fueron estas las fases a través de las cuales aquella facultad mimética que había sido el fundamento de la praxis oculta hizo su ingreso en la escritura y en la lengua. De tal suerte la lengua sería el estadio supremo del comportamiento mimético y el más perfecto archivo de semejanzas inmateriales: un medio al cual emigraron sin residuos las más antiguas fuerzas de producción y recepción mimética, hasta acabar con las de la magia." BENJAMIN, Walter. Sobre la facultad mimética. In: Angelus novus. Barcelona: Edhasa, 1971, p. 170.

${ }^{27}$ NEYNES, Gregorio. O caminho de Gilgamesh: vestígios para a reconstituição de um bailado, op. cit.

28 "La religión dionisíaca es la confesión de la democracia pues la naturaleza sensual a la que se dirige es patrimonio de todos los hombres, y no reconoce ninguna de las diferencias que establece el orden cívico o la pre-excelencia espiritual." BACHOFEN, Johann apud BENJAMIN, Walter. Johann Jakob Bachofen. Eco, Revista de la cultura de Occidente, Bogotá, n. 221, mar. 1980, p. 547.
} 
vanguardista de Nietzsche na França do entre-guerras. De Nietzsche (1992) e da revista Acéphale (2005) que, através da figura de Dioniso se empenhava na década de 30 - a década d'O caminho de Gilgamesh - numa reapropriação do pensamento nietzschiano, por esses anos sequestrado pelo fascismo, podemos tomar algumas características do trágico. Para eles, o culto de Dioniso era uma espécie de comunismo originário, uma ginecocracia, em que a vida cívica se sustentava por uma promiscuidade de elementos diferentes e não hierarquizados. Filho de Zeus e da mortal Sêmele ${ }^{29}$, Dioniso se vincula com a estrangeiridade ${ }^{30}$, com a ebriedade, com a errância, com a infância, com a festa, com a luxúria, com o feminino, com o telúrico, com o instintivo, com o popular, com o periférico, com o demoníaco, com o animal, com o sexual, etc.; em oposição ao Estado, à pátria, ao princípio de individuação, à autoridade, à forma, enfim, que Nietzsche identifica com Cristo e com Apolo. Dioniso, super-homem, como deus da desindividuação é o próprio nome do Anticristo, representa uma luta contra os poderes estabelecidos, uma sobressocialização perante a ordem social dada; por isso, a religião dionisíaca privilegia os vínculos por afinidade - ou "sympathia trágica", poderia se dizer - em detrimento dos vínculos de raça ou sangue, reúne os homens ao redor, não de ações definidas, mas da convicção de que a existência é o único valor absoluto e de que, carecendo de um sentido dado, ela é, em si mesma, trágica. ${ }^{31}$ Dessa maneira, o dionisíaco também é um dispositivo de memória, porque, para além da forma, exige rastrear a força, a vontade de ser. O trágico, em palavras de Nietzsche, é "o lúdico construir e desconstruir do mundo individual como arquiprazer"32, ou seja, uma compreensão do pensamento como um jogo ou luta entre a forma que se constitui e a força que o abre ao devir.

Em solo brasileiro, esse pensamento, que reúne noções do trágico, da sobrevivência, do vestigial, tem várias manifestações, de Araripe Jr. a Guimarães

${ }^{29} \mathrm{Na}$ mitologia grega, Dioniso era filho de Zeus e Perséfone. Esquartejado e devorado pelos Titãs, mas salvo por Atena e levado a Zeus, que engoliu seu coração, deu origem ao novo Dionísio Zagreu, filho da mortal Sêmele.

30 Dioniso é um deus oriental, daí que comumente seja associado a felinos de grande porte, inexistentes ou muito escassos no continente europeu. Nietzsche remonta o culto de Dioniso até uma pré-história na Ásia Menor e na Babilônia. NIETZSCHE, Friedrich Wilhelm. O nascimento da tragédia ou helenismo e pessimismo. Tradução, notas e posfácio J. Guinsburg. São Paulo: Companhia das letras, 1992, p. 30.

${ }^{31}$ Cf. Ibidem; e BATAILLE, Georges; KLOSSOWSKI, Pierre; CAILLOIS, Roger; MASSON, André; WAHL, Jean; MONNEROT, Jules; ROLLIN, Jean. Acéphale. Trad. Margarita Martinez. Buenos Aires: Caja Negra, 2005.

32 NIETZSCHE, Friedrich Wilhelm. O nascimento da tragédia ou helenismo e pessimismo, op. cit., p. 152. 
Rosa (quem chegou a falar da brasilidade como duende $e^{33}$ ), passando por outros muitos, mas talvez tenha a sua expressão mais acabada no pensamento antropofágico de Oswald de Andrade, que desenvolve em textos da década de 1940 ideias já esboçadas nos manifestos da década de 1920. Constatando que "a promiscuidade originária é um fato", ou que "as raças confinadas no seu mimetismo, cor-de-deserto, cor-de-pólo, cor-de-queimadura solar, longamente se mestiçaram"34, a antropofagia oswaldiana se ocupava em "Mensagem ao antropófago desconhecido" (1946) e A crise da filosofia messiânica (1950) em rastrear as sobrevivências do matriarcado na ordem social vigente e nas produções filosóficas do patriarcado ocidental, postulando para tal fim a criação de uma "errática"35, uma ciência capaz de discernir essa potência na barafunda de uma cultura que, em flagrante contradição dos próprios pressupostos, estaria também constituída pela devoração de outros e pela mistura dela decorrente. Um destino trágico, note-se, e a necessidade de uma arquileitura que consiga dar conta de arquiescrituras, de escrituras que operam como arquivos de semelhanças ou de vidas póstumas para além da mera representação de "ideias e outras paralisias". É uma opção pelos roteiros, note-se, um "acreditar nos sinais, nos instrumentos e nas estrelas", isto é, em efeitos de leitura traçados a partir de indícios e sintomas aparelhados por protocolos de interpretação, para além de conteúdos conscientemente incorporados aos textos.

Ora, no livro de Neynes se lê:

$33 \mathrm{O}$ duende, figura lorquiana, surge no clímax vital que aproxima dançantes, cantaores, poetas, toureadores, músicos, etc., da morte. Prazer e sofrimento, é um paroxismo existencial que, à maneira da tragédia nietzscheana, beira a dissolução tanto quanto abre novas existências. Por isso, para o García Lorca de "Juego y teoría del duende" (1933), "el duende ama el borde de la herida". LORCA, Federico García. Juego y teoría del duende. In: MAURER, Christopher (Ed.). Conferencias - Federico García Lorca. Madrid: Alianza Editorial, 1984, p. 104. Quanto à tentativa de definição da "brasilidade" do Guimarães Rosa que evocava a figura do duende, Cf. LORENZ, Günter. Diálogo com Guimarães Rosa. In: ROSA, João Guimarães. Ficção completa. v. I. Rio de Janeiro: Editora Nova Aguilar, 2009, p. LX.

${ }^{34}$ ANDRADE, Oswald. Do Pau-Brasil a Antropofagia e às Utopias. Rio de Janeiro: Editora Civilização Brasileira S. A., 1978, p. 85-86.

35 De fato, é de Nietzsche e Bachofen, das leituras desses autores, que Oswald, principalmente, deriva a sua proposta de uma Errática: "Devem-se a Bachofen, vulgarizado por Nietzsche, as primeiras pesquisas sobre o Matriarcado. Como já afirmamos, a cultura humana se dividiria em dois hemisférios - Matriarcado e Patriarcado. // Deriva o filho de Direito Materno do fato de que o primitivo não ligava o amor ao ato da geração. $O$ amor é por excelência o ato individual, e seu fruto pertence à tribo. // Será preciso criar uma Errática, uma ciência do vestígio errático, para se reconstituir essa vaga Idade de Ouro, onde fulge o tema central do Matriarcado." Ibidem, p. 88. 
Em cada um daqueles segmentos de caminho, o pé de Gilgamesh gravara um hieroglypho, o ideogramma de um estado de espirito feito gesto numa attitude mimica, num momento rythmico. [...] Foi necessário fizéssemos valer a estricta disciplina do methodo para que, a despeito das tentações, nos mantivessemos sempre a cís da choregraphia archeologica, vizinha. A' medida que restituíamos á ordem os fragmentos, a trama subterranea se tornava sensivel como a continuidade de um sentido sob a descontinuidade de um phenomeno. Nossos passos eram precedidos pela crescente predominancia de seu destino. E quando por fim tocamos nelle, foi como se do alto de um ponto de chegada tornassemos a ver o ponto de partida: o ultimo reflectia o primeiro. ${ }^{36}$

Esse "methodo" vestigial delirante, note-se, ao menos no tocante à ideia de destino em relação com uma arquiescritura, bebe em grande medida do pensamento antropofágico acima sumariamente caracterizado. Já nos aforismos d'O caminho de Gilgamesh, um leitor avisado pode reconhecer vários dos pressupostos antropofágicos, alguns dentre os quais passo a enumerar e exemplificar com citações. ${ }^{37}$ Encontrará, por exemplo, uma permanente apologia do impuro e misturado:

141. O impuro é um meio passo entre a debilidade do puro e a eternidade do purificado.

do marginalizado:

240. Procure-se onde está concentrada a maior carga de cultura irrealizada: dali partirá o golpe contra a civilização.

do artifício:

${ }^{36}$ NEYNES, Gregorio. O caminho de Gilgamesh: vestígios para a reconstituição de um bailado. Rio de Janeiro: Irmãos Pongetti, 1937, s/p.

37 Os pressupostos do que considero aqui um "pensamento antropofágico" podem ser rastreados tanto no Manifesto da poesia Pau-Brasil (1924) ou no Manifesto antropófago (1928), quanto nas intervenções oswaldianas na Revista de antropofagia ou nos textos da década de 1940, acima mencionados, "Mensagem ao antropófago desconhecido" (1946) e A crise da filosofia messiânica (1950). Por uma questão de espaço não vou me estender nesses pressupostos, mas atualizações desse pensamento podem ser consultadas em Cf. NODARI, Alexandre. "A posse contra a propriedade": pedra de toque do Direito Antropofágico. Dissertação (Mestrado), Programa de Pós-Graduação em Literatura, Universidade Federal de Santa Catarina, Florianópolis, 2007; Idem, La única ley del mundo. In: AGUILAR, Gonzalo. Por uma ciencia del vestigio errático (ensayos sobre la antropofagia de Oswald de Andrade), Buenos Aires: Grumo, 2010, p.107-166; Idem, O perjúrio absoluto (Sobre a universalidade da Antropofagia), CONFLUENZE, v. 1, n. 1, 2009, p. 114-135, Dipartimento di Lingue e Letterature Straniere Moderne, Università di Bologna. Cf. também, AGUILAR, Gonzalo. Por uma ciencia del vestigio errático (ensayos sobre la antropofagia de Oswald de Andrade). Buenos Aires: Grumo, 2010. 
159. Até aqui o homem tem nascido, simplesmente. Esperemos que ainda venha a ser premeditado.

247. Arte é creação.

248. Crear é desnaturar.

\section{do confronto:}

15. As coisas só se revelam nas collisões.

256. Não se esqueça o homem de que é fructo de uma transgressão de limites: essa origem é um presságio.

da insurreição:

359. Está inminente a insurreição do Homem.

36. Como afflige a um Deus não ter podido crear menos que um trespassador de fronteiras!

361. A mais alta conquista de um poder é engendrar um digno desapparecimento.

da voracidade cultural:

479. Nutri-me de voracidade.

430. O que se passa nas vísceras de um sábio é algo de muito violento.

417. Gozo da faculdade de só me saciar daquillo que me é negado.

418. No fim, quando não se tiver mais nada, tem-se fome.

119. Dedos cada vez mais delicados, sem garras a sustentar, ameaçam cahir.

428. Comi um prato de rabanetes e a seguir li um grande autor. Agora não consigo distinguir um do outro no que digo.

492. Estamos sentindo fomes para estômagos que ainda não temos.

de uma vida sem deus, ou da permanente transformação do tabu em totem:

369. Sempre deixamos um Deus para trás e pomos outro á nossa espera. É assim como todo Deus depende de nós para vir a ser. Tornemo-nos mais ligeiros para alcança-lo. Vês todas essas partes que lutam entre si? Cada uma é movida pela voracidade, ou amor, pelas outras. [...] Tudo o que nossa mais profunda vontade nos aconselha é o aborrecimento pela paz, o fastio pela permanência, fome pelo que nos falta, apego ao que nos sobra. Tudo diz: possue e goza. Alimenta-te bem para que sejas bom alimento ao seres devorado. [...] E assim te approximarás de um Deus que espera por ti para ser feito de ti e do que é contra ti. Se cambaleias, é porque te faltam pernas: serão tuas as que cobiçares, sejam de quem forem. Deus mesmo espera que o cobices. Tudo é para se cobiçar. 370. Deus é um ideal de potencia. 
Além desses postulados, o leitor d'O caminho de Gilgamesh também se deparará com uma "lógica" vestigial de pés firmemente fincados no chão (como o Abaporu [1928] de Tarsila do Amaral) - esse "plano axial dos acontecimentos humanos":

2. Não adeanta que o olhar, de um salto, se apodere do horizonte: nenhum caminho renuncia aos pés.

um repudio do patriarcado "messiânico":

38. Como é feroz e traiçoeiro o instincto de paternidade!

40. Paternidade, -até o fim haverá dúvidas.

399. A um foguete que se priva de cauda nem porisso se priva de destino.

um repúdio coerente da História como decurso teleológico homogêneo e cumulativo (que parece vir diretamente da Segunda consideração intempestiva de Nietzsche):

74. A solidariedade humana está na razão inversa da cultura histórica.

75. Os historiadores geram misanthropos.

uma recusa do valor atribuído à autoria e à herança:

274. Arte como expressão pessoal não é arte, é symptoma.

473. Ou penso, ou canto.

85. Os autores das grandes obras teriam existido ainda se não tivessem nascido.

$\mathrm{O}$ mesmo acontece, reciprocamente, com as grandes obras em relação a seus autores.

uma, consequente, exaltação da errância:

64. Graças a um previlegiado systhema de estomagos o erudito é capaz de qualquer deserto.

403. A decifração do enigma é: move-te ou morres.

da nudez:

13. O homem nasce nú e começa a vestir-se: máo signal. 
da experiência:

389. Compreender é trocar vida por vida.

488. Eis como se conquista uma paizagem: feita memória viva de alguém.

do ócio sobre o negócio:

121. A invenção do conforto é um requinte de desprendimento. Só o não entendem os recém-nascidos de espírito, sem edade hereditária.

233. Preconceito humano de máo destino: crear trabalho!

do excesso ou dom em detrimento da falta:

226. Toda gente experimenta agora a bem-aventurança de pedir, -não há mais quem dê: essa é a ameaça que pesa sobre as bellas palavras dos nossos antepassados. ${ }^{38}$

Para além desses conteúdos, O caminho de Gilgamesh é um livro constelacional e reversível, um jogo, à maneira da Rayuela (1961) de Cortázar, ou uma máquina celibatária que tenta pôr o acaso no seu centro, como aquelas ideadas por Mallarmé, por Roussel ou, posteriormente pelos patafísicos, ou por Marcel Duchamp. Sendo a primeira edição um livro de quatrocentos e noventa e seis aforismos ${ }^{39}$ numerados, precedidos por uma dedicatória e um texto introdutório, sem números de páginas, o livro se apresenta, como antes disse, e note-se o delírio, como a transcrição "nas letras da linguagem" das pegadas de Gilgamesh impressas em fragmentos de argila. ${ }^{40} \mathrm{Em}$ relação com esse sistema lúdico, já no início do livro, a dedicatória pode ser lida como um anúncio de seu caráter de jogo delirante: "Isto eu dedico a todos que vi fazendo desesperadas tentativas de se divertir." ${ }^{" 11}$ Constelacional, como disse, cada aforismo é precedido por um número, do 1 ao 496, e em alguns pontos um número na margem direita do texto reenvia a outro aforismo distante, porém intimamente ligado com aquele perante o qual se indica a chamada. Do total de afo-

38 Todas as citações anteriores estão em NEYNES, Gregorio. O caminho de Gilgamesh: vestígios para a reconstituição de um bailado, op. cit., s/p.

39 Seria possível ler $O$ caminho de Gilgamesh, também, numa constelação do aforismo no Brasil, que poderia incluir, por exemplo, O discípulo de Emaús (1945) de Murilo Mendes e os Cadernos de João (1957) de Aníbal Machado (especialmente o ABC das catástrofes).

$40 \mathrm{Ibidem}, \mathrm{s} / \mathrm{p}$.

${ }^{41} \mathrm{lbidem}, \mathrm{s} / \mathrm{p}$. 
rismos, exatamente sessenta e quatro incluem uma numeração em formato menor na margem direita, que funciona como um código de chamada para outros aforismos. No meio da leitura, por exemplo quando se chega ao aforismo 359:

359. Está imminente a insurreição do Homem. 257

Números à margem direita indicam os lugares de outros aforismos que devem ser lidos na sequência, neste caso o 257 e o 294 :

257. Um epílogo que ao mesmo tempo vem a ser o prólogo do drama seguinte: A insurreição de uma obra de arte que se fez carne. 294. Homem e Deus: Historia de uma inimizade.

Isso, como se vê, conforma um roteiro de leitura inusitado que, não raro, gera séries distintas da suposta pela ordenação linear da escrita. Ao terminar os aforismos, uma indicação ordena retornar ao primeiro deles:

\section{A aurora nasce apezar dos homens.}

\section{(Da capo)}

Figura 4 - Trecho final d'O caminho de Gilgamesh.

Assim como Um lance de dados (1897), como Finnegan's wake (1939), Tutaméia (1967) ou Galáxias (1963-1984), e como "Páramo" (1968) de Guimarães Rosa, o Caminho de Gilgamesh está composto segundo um princípio de reversibilidade: "Para cima não se vae -volta-se", ou "o ultimo reflectia o primeiro". ${ }^{42}$

Da capo, o lance de dados exige um novo lance, estimula uma leitura (escritura) inversa, outras constelações, sempre possíveis pela singular dispo-

$42 \mathrm{Ibidem}, \mathrm{s} / \mathrm{p}$. 
sição dos signos sobre o papel, isso porque, mesmo lançados, os significantes não escapam ao acaso dos acontecimentos de leitura. Se "compreender é trocar vida por vida", então devemos pensar que n'O caminho de Gilgamesh não é um sujeito-autor que fala (daí também a reversibilidade dos nomes GN/NG), não é uma autoridade que controla os sentidos, mas esses sentidos surgem do contato da máquina textual com os corpos que a operam em circunstâncias singulares não raramente atravessadas pelo acaso. É uma dança, uma arqueologia coreográfica, em que uma pulsão destrutiva, como diagnosticaria Derrida muito tempo depois em Mal de arquivo (1994), obriga o conjunto a uma permanente recombinação, que arroja resultados diversos a partir de princípios arcônticos diversos ${ }^{43}$ : é um arquivo vestigial que trabalha contra si próprio, como trabalha contra toda paternidade:

252. Toda creação exerce uma violencia. $208^{44}$

Ora, dançar é um gesto, e mais quando se trata de uma leitura dançada ou de um corpus de baile.... e a intervenção na segunda edição também pode ser interpretada como um gesto desestabilizador da própria escrita, de dessacralização da "obra" pela via da remontagem. Lembremos, a esse respeito, palavras de Flávio de Carvalho, do "Manifesto do II Salão de Maio" de 1939:

A arte deixa definitivamente de ser um ritual para ser um problema de sensibilidade maior; e, a propósito, não podemos deixar de relembrar a frase de Ana Pavlova: "dansem com as suas cabeças". 45

Em 2015, Luz Adriana Sánchez desenvolveu um projeto de pós-doutorado - submetido à Fundação Biblioteca Nacional - à procura de Gregorio Neynes/Nelson Geraldo. Dentre as informações que ela levantou, há algumas que agora gostaria de mencionar: Afrânio Coutinho e Octávio de Faria também possuíam exemplares com dedicatórias ${ }^{46}$; os editores no Rio, os irmãos

${ }^{43}$ Cf. DERRIDA, Jacques. Mal de archivo, una impresión freudiana. Trad. Paco Vidarte. 1994.

${ }^{44}$ NEYNES, Gregorio. $O$ caminho de Gilgamesh: vestígios para a reconstituição de um bailado, op. cit., s/p.

${ }^{45}$ CARVALHO, Flávio de. Manifesto do II Salão de Maio. Revista Anual do Salão de Maio, n. 1, São Paulo, maio 1939, p. 11.

${ }^{46} \mathrm{Na}$ Biblioteca da Faculdade de Letras da UFRJ, existem também dois exemplares, associados ao acervo de Afrânio Coutinho, que, segundo as informações catalográficas contam também com dedicatória do autor para Octávio de Faria; assim como na Biblioteca da Escola de Belas Artes da UFMG onde há também um exemplar. 
Pongetti, tiveram contato com outros modernistas, como Carlos Drummond de Andrade, que dá um depoimento no livro homenagem Ruggero Pongetti, uma vida dedicada ao livro ${ }^{47}$; no Diário Oficial da União, de 2 de junho de 1938, mencionam-se Nelson Geraldo Esteves e Neynes, como nome de autor e pseudônimo, numa solicitação de registro da obra $O$ caminho de Gilgamesh ${ }^{48}$; nasceu em 1912, provavelmente no Rio de Janeiro ${ }^{49}$, lá foi aluno do Gymnasio Anglo-Brasileiro ${ }^{50}$; se formou em Filosofia, do College of Letters and Science da Universidade de Califórnia, em 24 de fevereiro de 1945 ${ }^{51}$; foi funcionário do Ministério das Relações Exteriores e morreu em 199852; segundo o Jornal do Brasil de 12 de abril de 1928, provavelmente foi um praticante amador de rowing. ${ }^{53}$

Uma pesquisa mais recente lançou informações sobre duas pequenas publicações. Uma delas é um artigo crítico sobre o poeta Charles Eaton (que foi

47 Ruggero Pongetti, uma vida devotada ao livro. Rio de Janeiro: Irmãos Pongetti, 1963. No Centro de Documentação Cultural "Alexandre Eulalio" (CEDAE) da UNICAMP, especificamente na pasta tombada com o número catalográfico FC_Album_2 do Fundo Flávio de Carvalho, que contém informações sobre o Clube dos Artistas Modernos (CAM) e o teatro da Experiência, se encontra um recorte da Folha da noite de 28 de janeiro de 1933, notícia de uma palestra de Henrique Pongetti no CAM. Na mesma pasta há recortes sobre palestras de Agrippino Grieco.

48 Do Diário Oficial, 2 de junho de 1938 (Secção I, página 92): "N. 6.023 - Requerido pelo autor Nelson Geraldo Esteves, brasileiro, residente à rua Senador Dantas, número 19, apartamento número 810, nesta capital: - 'O caminho de Gilgamesh'. Vestígios para a reconstituição de um bailado. Um volume com 126 páginas inumeradas. O autor usa na obra o pseudónimo de Neynes, impresso no corrente ano, nesta capital."

${ }^{49}$ Como consta no verbete "GERALDO, Nélson (N.G. Esteves, Rio de Janeiro, 1912-)", em: COUTINHO, Afrânio; SOUZA, José Galante. Enciclopedia de literatura brasileira. v. I. São Paulo: Global Editora; Rio de Janeiro: Fundação Biblioteca Nacional/DNL; Academia Brasileira de Letras, 2001, p. 651. No mesmo verbete dessa enciclopédia, se registra que Nelson Geraldo Esteves foi professor, filósofo, diplomata e jornalista. Lembremos que no registro de imigrações de judeus na Argentina se informa a lista de passageiros do navio Antonio Delfino, que aportou em Buenos Aires no dia 11 de abril de 1938 trazendo imigrantes judeus em fuga da Europa. Nesse registro se afirma que a idade de Nelson Geraldo Esteves é 25 anos, e que nasceu no Rio de Janeiro. Essas informações parecem corroborar a data e o lugar de nascimento do autor.

50 Segundo a "Relação dos alunos inscriptos aos exames de primeira época do ano letivo de 1925", incluída no suplemento do Diario Official de 14 de novembro de 1925.

${ }^{51}$ Como consta no livro de registro da própria instituição, correspondente ao período 19441945.

52 Como o sugere a publicação da concessão de sua pensão - Pensão Civil - no Diário Oficial (DOU), em 17 de agosto de 1998. O professor Raúl Antelo, através de contatos na diplomacia, procurou outras informações sobre Neynes/Nelson Geraldo, sem sucesso. Devo ao professor Antelo, no entanto, o achado de Neynes a bordo do navio Siqueira Campos em 1939, assim como a menção na lista de passageiros do navio Antonio Delfino, que aportou em Buenos Aires no dia 11 de abril de 1938.

53 Jornal do Brasil, Rio de Janeiro, 12 abril 1928. 
vice-cônsul dos Estados Unidos no Brasil, entre 1942 e 1946). Esse artigo é um comentário do livro The bright plain (1942), se intitulou "Um poeta americano" e foi publicado na revista Ribeu em setembro de $1943 .{ }^{54}$ A outra publicação é um poema, intitulado precisamente "POEMA", que Neynes divulgou em Ocidente: revista portuguesa mensal (Abril/Maio 1939) ${ }^{55}$ :

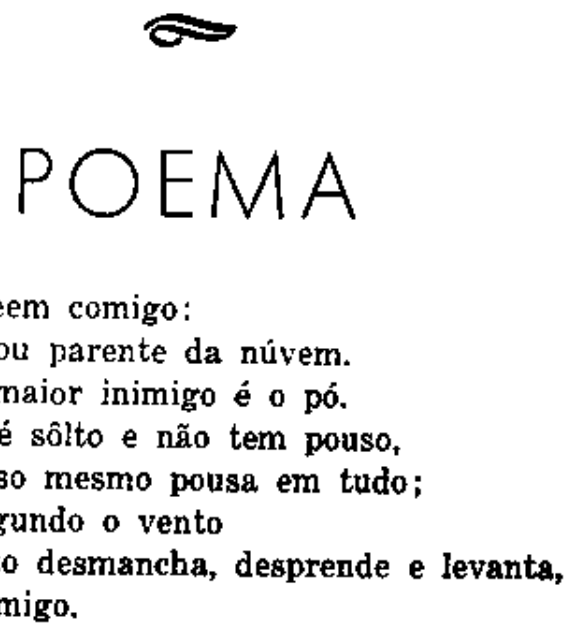

Minha gente é a que está segura, sempre quieta.

Amo a pesada corrente e o castelo de ferro.

Amo o centro da terra. Amo tudo que fiea, amo tudo que espera aquela māo pesada e dura que, no fim, vira para que fique: na terra, um Hovrax 86 .

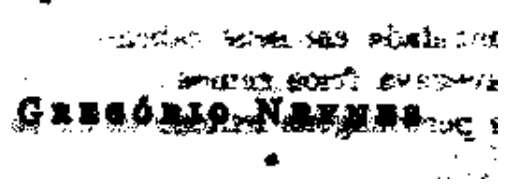

Não por um acaso, no mesmo volume de Ocidente - revista estadonovista lusa sintonizada com Antonio Ferro e as ideias do Eugênio D'Ors das "quatro Espanhas" - se incluem poemas de Cecília Meireles ("Canção de um naufrágio antigo") e de Mário Quintana ("Inquietação"). Isso marca um certo paradoxo, pois apesar do dionisismo d'O caminho de Gilgamesh, dionisismo

\footnotetext{
54 Segundo consta na p. 343 de uma Bibliografia de Obras Norte-americanas em Tradução Portuguesa, preparada por John E. Englekirk (Tulane University). Segundo a mesma bibliografia, em 1945, na mesma revista, Domingos Carvalho da Silva e Oswaldino Marques publicaram traduções de poemas de Eaton.

55 NEYNES, Gregório. POEMA. Ocidente: revista portuguesa mensal, v. 5, n. 12-13, p. 217, abril/maio 1939.
} 
caro à teoria do barroco de Eugenio D’Ors, de 1935, o Neynes de 1939 opta, como fizera o próprio filósofo catalão, pelas "formas que pesam" e não pelas "formas que voam" 56 , pois o "POEMA" parece uma apologia do castelo de ferro, da mão dura e das pesadas correntes da ditadura salazarista. Isso dá conta de uma "evolução" nada estranha à de alguns integrantes do movimento antropofágico, como Tristão de Ataíde ou, mais radicalmente, Plínio Salgado, pois se o Neynes de 1937 era um pensador dos pés dançantes, o de 1939 parece escrever seu "POEMA" com os "cinco abnegados dedinhos de mão negra conservadora" que, através de uma "Nota insistente" Alcântara Machado e Raul Bopp tentavam conjurar já nos primeiros números da Revista de antropofagia. ${ }^{57}$ (Nuançando um pouco as coisas, e como pode se constatar pela leitura atenta de cada um dos aforismos d'O caminho de Gilgamesh, o Neynes dançante já era em germe conservador, inclusive por um viés nietzschiano, mas ao consagrar o texto à constelação e à reversibilidade de alguma maneira privilegiava as formas que voam, pois, como antes sugeri, esse tipo de dispositivo - estelar - retira a centralidade semântica do enunciado e faz da performance de leitura o motor excêntrico da produção de sentido).

Para além dessas publicações, e voltando ao "objeto" deste trabalho, sabemos que Neynes estudou filosofia, na Universidade de Califórnia, sob o nome Nelson Geraldo. Nessa instituição, provavelmente, estudou a obra de James George Frazer, The golden bough (1890), livro em que, aliás, como nos informa Larissa Costa da Mata na sua tese Genealogia e primitivismo no mundo

\footnotetext{
${ }^{56}$ Cf. D'ORS, Eugenio. Lo barroco. Madri: Alianza, 2002.

57 Vale a pena lembrar que a publicação antropófaga se caracterizava nos seus primórdios por grande ecletismo, tão evidente para os seus responsáveis, Alcântara Machado e Raul Bopp, que inclusive precisaram esclarecer, em "Nota insistente" colocada no final do primeiro número: "Ella [a Revista] está acima de quaisquer grupos ou tendências; [...] -Ella nada tem que ver com os pontos de vista de que por acaso seja veículo. A 'Revista de Antropofagia' não tem orientação ou pensamento de espécie alguma; só tem estômago". Revista de antropofagia. Edição fac-similar com prólogo de Augusto de Campos. São Paulo: Abril Cultural, 1975, p. 24. A partir da segunda dentição da Revista, os nacionalistas reunidos no Grupo de Anta foram rejeitados pelo movimento antropofágico, assim como o nacionalismo verde-amarelo: "O que louvamos nesses cinco abnegados dedinhos de mão negra conservadora é uma coragem -a de se declararem sustentáculos de um ciclo social que desmorona por todos os lados e grilos de um passado intelectual e moral que nem na Itália está mais em voga! Pândegos! [...] Os verdeamarelos daqui querem o gibão e a escravatura moral, a colonização do europeu arrogante e idiota e no meio disso tudo o guarani de Alencar dançando valsa. Uma adesão como essa não nos serve de nada, pois o 'antropófago' não é indio de rótulo de garrafa. Evitemos essa confusão de uma vez para sempre! Queremos o antropófago de knicker-bockers e não o indio de opera." CAMPOS, Augusto. Prólogo. Revista de antropofagia. Edição fac-similar com prólogo de Augusto de Campos. São Paulo: Abril Cultural, 1975, p. 11.
} 
perdido brasileiro ${ }^{58}$, Flávio de Carvalho escreveu, na contracapa do seu exemplar de 1933, uma referência à Epopeia de Gilgamesh (2.500-2.000 a.C.) como origem do ritual de abençoamento. ${ }^{59}$ De fato, em $A$ origem animal de deus (1973), Flávio aponta: "O herói é essencialmente um homem medroso. Apontamos o meio invencível que o herói Guilgamish tinha da morte, e o qual foi a grande preocupação de todos os seus atos."60

Joyce, Lezama Lima, Yeats, Eliot, Oswald, Mário, Raul Bopp, entre outros, foram ávidos leitores de Frazer, e acredito que todos eles, como Flávio, ficaram fascinados com a tese de que a origem de ciência, política e, principalmente, religião é a crença num deus que morre (uma magia que não dá certo), e no subsequente sacrifício ritual de um rei sagrado que representa a esse deus e que renasce em cada nova colheita. Em A origem animal de deus, texto escrito em 1967, ou seja, no mesmo ano da reedição portuguesa d'O caminho de Gilgamesh, mas só publicado em 1973, junto com a peça O bailado do deus morto - ou seja de Gilgamesh ou Enkidu, como explicitarei mais adiante - , nesse ensaio Flávio (antropófago arquiconhecido), num estilo aforístico, nietzschiano, semelhante ao de Neynes, também insiste numa ideia de Neynes (o antropófago desconhecido). Essa ideia me parece uma revisão de Frazer, porque para Carvalho, e para Neynes, a origem da religião não é exatamente a magia, mas a fome:

58 DA MATA, Larissa Costa. Genealogia e primitivismo no mundo perdido brasileiro: 0 mundo perdido de Flávio de Carvalho, op. cit., p. 104.

59 De acordo com a Dra. Larissa Costa da Mata, é pouco clara a grafia dessa anotação, e poderia também se tratar de uma referência ao livro $O$ mecanismo da emoção amorosa, que fora escrito inicialmente em 1934, com motivo de uma conferência que Flávio de Carvalho apresentara em Praga no mesmo ano, com Roger Caillois, e que fora ampliada e recebera anotações manuscritas até 1952. Segundo a Dra. Larissa, em e-mail de 11 de outubro de 2015, Flávio de Carvalho menciona em O mecanismo da emoção amorosa que a lenda da epopeia de Gilgamesh foi estabelecida por L. W. King, de uma publicação do Museu Britânico. Em e-mail do dia 10 de outubro do mesmo ano, endereçado a Larissa respondendo a consulta por mim solicitada, o Prof. Dr. Rui Moreira Leite disse que a Epopeia de Gilgamesh é uma das poucas leituras do período de formação que o próprio artista menciona (em entrevista com Silveira Peixoto), juntamente com algumas lendas africanas - entre elas a "Comida das duas mulheres", que conta a história de uma mulher primordial, Wagadu, que havia dotado os homens com o poder do canto e as mulheres com o poder da escrita, um instrumento de dissimulação e de engano. É possível que a edição das lendas babilônicas e africanas consultada por Flávio seja a do Museu Britânico (consta na biblioteca do escritor, em edição organizada por E. A. W. Budge).

60 CARVALHO, Flávio de. A origem animal de deus / O bailado do deus morto. São Paulo: DIFEL, 1973, p. 42. 
É no aparelho digestivo onde nascem os deuses do mundo. [...] A sensação de religião é gerada na sensação de fome. A satisfação religiosa é a satisfação da fome. [...] o ato de devorar é a primeira religião do homem. [...] $\mathrm{O}$ ato de fé consiste na carícia bucal e intestinal. ${ }^{61}$

Sem mais aprofundamentos nessa revisão, voltemos à Epopeia de Gilgamesh (2.500-2.000 a.C.), referência comum a ambos os autores. Como o protagonista/narrador de "Páramo", e como o deus de O bailado do deus morto, o herói da epopeia não consegue a imortalidade, nem alcançar um caráter divino, nem a ressurreição do seu amado Doppelgänger Enkidu - semideus de origem anima ${ }^{62}$ - , igual às feras do mato, estado animal a que Gilgamesh retorna após a morte do amigo. ${ }^{63}$ De fato, Enkidu é o protagonista de $O$ bailado do deus morto, e aparece assim descrito em $A$ origem animal de deus, livro vestigial entre os livros vestigiais:

Encontramos entre os animais da floresta, comendo ervas, o herói-homem divinizado, Enkido, o rival do fabuloso Guilgamish. Enkido tinha o corpo coberto de longos pelos e cabelos compridos como os da mulher e era invencível e se vestia como mulher, com folhas, imitando a deusa Gira. ${ }^{64}$

${ }^{61}$ Ibidem, p. 9-11.

62 A seguir, a respeito dessa origem animal, cito um trecho tomado do Texto do programa histórico distribuído na estreia d'O bailado do deus morto: "O primeiro ato trata da origem animal do Deus, o aspecto e as emoções do monstro mitológico, a vida do Deus pastando entre as feras do mato e os laços afetivos que mantinha com estas." Ibidem, p. 97. Não por um acaso, essa origem animal deve ser rastreada a partir de uma ciência do vestígio errático, em nada alheia a um uso fundante da crença e para além do seu caráter constituído, como se pode constatar em "A Epopeia do Teatro da Experiência e o Bailado do Deus Morto", relato publicado por Flávio na Revista Anual do Salão de Maio de 1939: "Entre um coro de mugidos de vaca de manhã cedo os homens do mundo imploram em vão um Deus calado e desaparecido. Perplexos, eles decidem e controlam os destinos do pensamento, marcam e especificam o fim do Deus e o modo de usar os seus resíduos no novo mundo." Idem, A Epopeia do Teatro da Experiência e o Bailado do Deus Morto. Revista Anual do Salão de Maio, n. 1, São Paulo, maio 1939 , p. 50.

63 Cito, a respeito dessa regressão a um estado animal, um trecho das Notas para a reconstrução de um mundo perdido: "Uma ameaça de perigo provoca, para fins de defesa, reversão a um estado ancestral antigo. O elemento ameaçado refugia-se no tipo ancestral. Todas as vezes que um perigo iminente ameaça um ser vivo, ele procura segurança revertendo a imitação de um tipo ancestral e de um estado antigo. Ele foge de um estado evoluído especializado e, acertadamente, refugia-se na alta plasticidade de um estado primitivo. A situação de perigo provoca o retrocesso na sua evolução, isto é, uma involução e a volta para trás rumo a um período mais plástico." Idem, Os gatos de Roma / Notas para a reconstrução de um mundo perdido. Transcrição de Larissa Costa da Mata. In: DA MATA, Larissa Costa. Genealogia e primitivismo no mundo perdido brasileiro: o mundo perdido de Flávio de Carvalho, op. cit., p. 114. ${ }^{64} \mathrm{Idem}, A$ origem animal de deus / O bailado do deus morto. São Paulo: DIFEL, 1973, p.46. 
A Epopeia de Gilgamesh é a epopeia de um robusto fracasso, e o seu protagonista é algo assim como o protótipo do deus que morre (segundo a narrativa, ele pode alcançar a imortalidade, só que a sua caminhada, tragicamente, ou seja, pelos seus próprios feitos, o aproxima da extinção). É assunto romanesco moderno, poderíamos pensar, com o que notamos um anacronismo já nessa narrativa antiquíssima. A própria epopeia diz o que o herói trouxe da sua longa caminhada:

Isto também foi obra de Gilgamesh, o rei, que percorreu as nações do mundo. Ele era sábio, ele viu coisas misteriosas e conheceu muitos segredos. Ele nos trouxe uma história dos dias que antecederam o dilúvio. Partiu numa longa jornada, cansou-se, exauriu-se em trabalhos e, ao retornar, descansou e gravou na pedra toda a sua história. ${ }^{65}$

O grande construtor e juiz dos mortos dos sumérios, Gilgamesh, trouxe a estória do dilúvio. Daí o interesse que esse mito despertou nos etnógrafos e arqueólogos do século XIX, interesse que teve imensa relevância para o desenvolvimento da antropologia moderna, pois esse dilúvio antiquíssimo desestabilizava a originalidade do mito bíblico, deslocando por sua vez a centralidade e pureza de uma cultura de referência. ${ }^{66} \mathrm{Na}$ Epopeia de Gilgamesh, a narrativa do dilúvio abarca a tentativa, falha, dos deuses de aniquilar a balbúrdia de uma espécie demasiado barulhenta - a babélica humanidade. Também a estória de alguém que procurou a imortalidade junto a Utnapishtim, o Noé da epopeia, que salva da catástrofe cósmica animais e família num barco, mas que declara a Gilgamesh a futilidade da sua tentativa:

Não existe permanência. Acaso construímos uma casa para que fique de pé para sempre, ou selamos um contrato para que valha por toda a eternidade? Acaso os

65 Anônimo. A epopeia de Gilgamesh. Trad. Carlos Daudt de Oliveira. São Paulo: Martins Fontes, 2011, p. 108.

66 Os primeiros vestígios da Epopeia foram achados em Nínive, em escavações que começaram em 1839, sob os cuidados de Henry Layard, na Biblioteca de Assurbanípal, soterrados junto com os de outras composições. Trata-se de doze tábuas de argila que guardam impressões de escrita cuneiforme, com aproximadamente trezentos versos cada uma, cuja decifração não só revelou a história de Gilgamesh, mas representou o primeiro momento do mapeamento de sua circulação e registro. Sua história compreende um mistério, pois restam dela apenas fragmentos de várias versões - suméria, hitita, acadiana - decifradas, dispostas e cotejadas, que falam de tudo menos de uma origem única e verdadeira. Cada fragmento de argila inscrita é um vestígio de sua passagem, reconstituível somente através de procedimentos de montagem e remontagem. A respeito de alguns desdobramentos, pesquisas e debates em torno do mito do dilúvio encontrado na Epopeia de Gilgamesh, Cf. SANDARS, Nancy Katherine. Introdução. In: A epopeia de Gilgamesh, op. cit., p. 3-58. 
irmãos que dividem uma herança esperam mantê-la eternamente, ou o período de cheia do rio dura para sempre? Somente a ninfa da libélula despe-se da larva e vê o sol em toda a sua glória. Desde os dias antigos, não existe permanência. ${ }^{67}$

Talvez apenas existam as estórias, lugares não de permanência, mas de vida póstuma, de vagalumes, ninfas ou libélulas. No caso desse deus mortal, apenas restam seus vestígios e seu nome gravados em tábuas de argila, "os pontos de contato com este plano axial dos acontecimentos humanos -o chão", resíduos da vida vivida com que a divina Siduri - aliada do herói parece querer dissuadi-lo do seu propósito fútil de imortalidade:

\begin{abstract}
Gilgamesh, onde vais com tanta pressa? Jamais encontrarás a vida que procuras. Quando os deuses criaram o homem, eles the destinaram a morte, mas a vida eles mantiveram em seu próprio poder. Quanto a ti, Gilgamesh, enche tua barriga de iguarias; dia e noite, noite e dia, dança e sê feliz, aproveita e deleita-te. Veste sempre roupas novas, banha-te em água, trata com carinho a criança que te tomar as mãos e faze tua mulher feliz com teu abraço; pois isto também é o destino do homem. ${ }^{68}$
\end{abstract}

Este trabalho é também, de alguma forma, a comunicação de um fracasso. Por isso, a saída deste texto é forçosa (como, aliás, é o fechamento de todo texto). Pela própria obstinação com que Neynes se esconde atrás, ou melhor: além de seus vestígios, incluídos seus nomes reversíveis, o crítico dança. Dança, por enquanto, quem pesquisa sem encontrar outra coisa que alguns links que permitam uma potencial legibilidade. Neynes/Geraldo apenas deixou alguns vestígios, a sua errância de perseguido, um poema, um artigo crítico, um jogo, esse livro do caminho, alguns documentos, mais não encontrei; a outra obra, o resto enorme de toda uma vida, fica na invisibilidade, por enquanto. Nelson Geraldo Esteves (esteve uma vez, esteve mais de uma), como Matraga, não é nada. Neynes, não, nein, néant, nonada. Todavia, procurar Neynes também pode ser bailar, e mesmo não sabendo muito bem como fazer isso, mesmo com pernas ou pés de chumbo, procurá-lo é a própria atividade e a vida do leitor. No instante em que deixo de acreditar nele, "Neynes" desaparece.

67 Ibidem, p. 99-100.

68 Ibidem, p. 95. 